\title{
Regulatory Action Criteria for Filth and Other Extraneous Materials
}

\author{
III. Review of Flies and Foodborne Enteric Disease
}

\author{
Alan R. Olsen ${ }^{1}$ \\ Microanalytical Branch, HFS-315, Center for Food Safety and Applied Nutrition, U.S. Food and Drug Administration, \\ 200 C Street, Southwest, Washington, DC 20204
}

Received October 22, 1998

\begin{abstract}
Forty-seven species of flies have been reliably associated with filthy conditions that might allow the spread of foodborne pathogens. These are categorized as "filth flies." Of that 47 , only 21 species represent a potential threat to human health as scientifically proven causative agents of foodborne myiasis or as carriers of enteropathogenic Escherichia coli, Salmonella, Shigel la, and other foodborne pathogens. These 21 species are categorized as "disease-causing flies" based on strict scientific criteria. The criteria are association with E. coli, Salmonella, AND Shigella; synanthropy; endophily; communicative behavior; attraction to both excrement and food products; and recognition by authorities as a potential health hazard. Within Hazard Analysis and Critical Control Point and other U.S. Food and Drug Administration regulatory frameworks, disease-causing flies are contributing factors to the spread of foodborne disease that require preventive and corrective actions as appropriate under Sanitation Standard Operating Procedures, Good Manufacturing Practices, or pest control programs.
\end{abstract}

\section{INTRO DUCTION}

In the early decades of this century, flies were justly despised as purveyors of disease. With the advent of modern pest control chemicals, the direct impact of flies on the public health seemed to decline, leading to a false sense of security about the health threat that flies represent (West, 1951). Studies such as those of Watt and Lindsay (1948), Lindsay et al. (1953), Levine and Levine (1990), and Cohen et al. (1991) show how, even in modern times, inattention to sanitation can allow flies to spread foodborne diseases.

Fly contamination in food has always been a concern of the U.S. Food and Drug Administration (FDA) and

\footnotetext{
${ }^{1}$ Assisted by Sherry A. Knight.
}

its predecessors. In 1927, the federal Food, Drug, and I nsecticide Administration issued a tolerance for insect filth in figs that included infestation with "vinegar flies" (Drosophilidae) (Howard, 1929). Postwar FDA publications on filth in foods include a number of articles on fly contamination in food products (Sabatino, 1954; Carson and Martinez, 1967; Gorham, 1979; Olsen et al., 1993). The Agency includes flies in its manuals as significant types of filth (Gorham, 1981; Gorham, 1991a, b; Olsen, et al., 1996) and has issued guidance for seafood products that defines "filth flies" to the taxonomic family level (Wisnioski, 1994). Flies are singled out in the Code of F ederal Regulations 21 CFR 110.3(j) (Food and Drug Administration, 1997a) as a type of pest to be excluded from food-handling areas.

Traditionally, FDA has interpreted evidence of insanitation associated with flies on a case-by-case basis in relation to sections 402(a)(3) and 402(a)(4) of the F ood, Drug, and Cosmetic Act. Section 402(a)(3) deems a food adulterated "if it consists in whole or in part of any filthy, putrid, or decomposed substance, or if it is otherwise unfit for food." Section 402(a)(4) deems a food adulterated "if it has been prepared, packed, or held under insanitary conditions whereby it may have become contaminated with filth, or whereby it may have been rendered injurious to health." To date, there has been no systematic effort to refine the Agency's interpretation of fly contamination to fit modern Hazard Analysis and Critical Control Point (HACCP)based concepts of food sanitation, especially in relation to the prevention of foodborne disease under the "rendered injurious to health" provision of section 402(a)(4) of the Food, Drug, and Cosmetic Act. Refinement is needed because, of the thousands of different types of flies, relatively few are associated with foodborne disease. Of the flies that are associated with foodborne disease, even fewer pose a realistic threat to the health of the consumer.

There are 108 families of flies containing over 
120,000 species (Borror et al., 1989). Fewer than 350 fly species in 29 families are associated with the spread of disease and even fewer are associated with the spread of foodborne disease (Greenberg, 1971). Many reports of association of a fly species with foodborne pathogens are less than compelling from a public health and food sanitation standpoint. Current food safety guidance concerning fly contamination lacks the precision that is needed to differentiate the few flies that pose a true threat of the spread of disease from the many types of flies that pose a minimal health risk as potential transmitters of foodborne disease pathogens.

An example of imprecision in current guidance regarding fly filth is the blanket categorization all flies of the family Muscidae as "filth flies" (Wisnioski, 1994). Many of the Muscidae, however, are not associated with filth or insanitation (Skidmore, 1985, McAlpine, 1987). On the other hand, the Muscidae include the house fly, Musca domestica L., perhaps the most notorious transmitter of disease since Typhoid Mary. What is needed is refinement of the interpretation of fly contamination in foods, especially those foods that fall under the new HACCP framework.

The purpose of this review is to partition out the fly species that are reasonably likely to contribute to the spread of foodborne disease. The FDA and other food sanitation regulators can then refine the interpretation of fly filth to differentiate contamination by flies that spread disease from fly filth that represents no immediate threat to the public health. This is the third report of a series in the development of a transparent science base for a revised FDA regulatory policy in the area of filth and extraneous materials in food.

\section{METHODOLOGY}

The definitive work on the associations of flies with disease was published by Greenberg $(1971,1973)$. This review supplements Greenberg's work with literature from the period 1970-1997. Information about specific foodborne pathogens was obtained from the FDA CFSAN website. Standard authoritative texts for the groups involved were used to confirm taxonomies, be havioral traits, and other biological information concerning flies (Cole, 1969; Delfinado and Hardy, 1975; Evenhuis, 1989; Ferrar, 1987; Hall, 1948; J ames, 1947; McAlpine, 1987; Oldroyd, 1964; Pape, 1996; Skidmore, 1985; West, 1951; Zumpt, 1965).

\section{INTESTINAL MYIASIS}

Intestinal myiasis is an invasion of the gastrointestinal tract by fly larvae. The source of intestinal myiasis is contaminated food. Scientific authorities generally agree that certain flies pose a risk to the public as agents of intestinal myiasis, especially in food contaminated by flies at the retail or consumer levels of prep- aration (Harwood and J ames, 1979; J ames, 1947; Godard, 1993; Greenberg, 1973; Zumpt, 1965). Haines and Rees (1989) warn that consuming fish contaminated by flies can result in intestinal myiasis. Akinbode et al. (1989) gave a similar warning for meat. In the literature cited below, suspect foods included fruit, undercooked or raw meat, cheese, and cooked chicken ("yakitori").

Intestinal myiasis is a rare disease. Scott (1964) reported 28 cases of intestinal myiasis in the United States over an 11-year period (1952-1962 inclusive). About two or three cases of intestinal myiasis are reported annually in the literature (Laurence, 1986; Tachibana et al., 1987; Ferreira et al., 1990; Shiota et al., 1990; Nakagura et al., 1991; Hasegawa et al., 1992; J umaian et al., 1995; Lee et al., 1995; Chung et al., 1996). Recent morbidity statistics for calendar year 1984 report nine cases of intestinal myiasis over a year's time (Madison et al., 1985) and there are undoubtedly many unreported cases (Laurence, 1986).

All segments of the population are at risk of myiasis from contaminated food (Godard, 1993; J umaian et al., 1995; North, et al., 1987). Normally, the seriousness of intestinal myiasis is limited (transitory minor disability and annoying complaints) (J ames, 1947; Zumpt, 1965), but it can become moderate (transient but significant disability) when the fly larvae embed themselves in the appendix or otherwise damage the tissue of the intestine (Harwood and J ames, 1979; Kenney et al., 1976). Although flies cannot grow to maturity and reproduce in the gastrointestinal tract, there is evidence that larval development takes place there (Banks, 1912; J ettmar, 1940; J ames, 1947; Busvine, 1966; Barkin et al., 1983).

The literature on intestinal myiasis has been extensively reviewed (J ames, 1947; Baumgartner, 1988; Zumpt 1965). Data from these reviews can be combined with data from more recent reports of intestinal myiasis (e.g., Furman et al., 1959; Kilpatrick and Schoof, 1959; Scott and Littig, 1964) to derive a list of flies that are reliably reported to cause intestinal myiasis in humans. The resulting list is summarized in Table 1.

Reports that are based solely on finding larvae in stool samples are not conclusive proof of foodborne myiasis. Several explanations for this phenomenon are possible. A report of intestinal myiasis must contain additional observations that verify the foodborne origin of the fly larvae in order to be credible (Busvine, 1966). Additional observations may include surgical recovery of fly larvae from a victim's intestine, recovery of fly larvae from food consumed by a victim, recovery of fly larvae from vomit, or recovery of fly larvae from a victim's stool under clinical conditions where the possibility of cross-contamination was controlled. Table 1 is based on reports of intestinal myiasis that meet this additional observation criterion. 
TABLE 1

Examples of Fly Species Known to Cause Intestinal Myiasis in Humans
Fly species
Family
References

Megaselia insulana Brues

Piophila casei (L.)

Hermetia illuscens (L.)

Erstalis tenax (L.)

Fannia spp.

Muscina stabulans (Fallén)

Stomoxys calcitrans (L.)

Calliphora vicina (Robineau-Desvoidy)

Phormia regina (Meigen)

Phaenicia cuprina Wiedemann

Sarcophaga (including J antia) spp.
Phoridae

Piophilidae

Stratiomyidae

Syrphidae

Muscidae

Muscidae

Muscidae

Calliphoridae

Calliphoridae

Calliphoridae

Sarcophagidae
Ferriera et al., 1990

Zumpt, 1965

Nagakura et al., 1991; Lee et al., 1995

J ames, 1947

J ames, 1947

Laurence, 1986; North et al., 1987

Ferriera et al., 1990

Zumpt, 1965

Kenney et al., 1976

J umaian et al., 1995

Kenney et al., 1976; Tachibana et al., 1987; Shiota et al., 1990

\section{THE FLY AS A CARRIER OF DISEASE}

The evidence relating to the transmission of foodborne pathogens by flies consists of case control epidemiological studies, fly population suppression studies and field studies of transmission by flies that are fed from infected reservoirs. As passive vectors, certain flies are capable of contaminating food with Shigella, Salmonella, disease-causing Escherichia coli, Campylobacter jejuni, Vibrio cholera, and other foodborne pathogens (Greenberg, 1973; Levine and Levine, 1991). In this situation, flies amplify the risk of foodborne disease by transporting pathogens from places where the pathogens pose no hazard to places where they do (Gorham, 1989). All segments of a population are at risk of gastroenteritis from food contaminated with the pathogens noted above. The seriousness of gastroenteritis is limited (transitory minor disability; annoying complaints) unless a patient's health is otherwise compromised (Bean et al ., 1990). I nfant morbidity and mortality from gastroenteritis is generally higher than that of other groups, but the literature contains no reports that link a fly-related epidemic with elevated infant mortality. The sources of epidemics of foodborne illnesses are unknown in approximately one-fourth of the incidents reported each year (Bean et al., 1990) and flies may contribute to some of these (West, 1951).

Flies are holometabolous insects, with a life cycle that includes egg, larva, pupa, and adult. The larvae of muscoid flies, eg., families Muscidae (house flies), Calliphoridae (blow flies), and Sarcophagidae (flesh flies), are headless, legless vermiform maggots. Adults are bristly robust flies, generally $5 \mathrm{~mm}$ or more in body length. A typical life cycle (egg to adult) ranges from 1 week to 2 months under normal environmental conditions. F emales may lay up to 700 eggs in a lifetime and there may be 6 to 10 or more generations per year (J ames, 1947). The typical muscoid adult has been demonstrated to transmit pathogens on the sponging mouthparts, through vomitus, on body and leg hairs, on the sticky pads of the feet, and through the intesti- nal tract (Radvan, 1960). It has been demonstrated that the microorganisms on a fly's body are disseminated by direct contact (Sulaiman et al ., 1988; Sramova et al., 1992; Richards et al., 1961; Paraluppi et al., 1996; Greenberg, 1964; Echeverria et al., 1983; De Capito, 1963; Bolanos, 1959; Akinbode et al., 1989; Khin et al., 1989), in fly feces (Greenberg et al., 1970), and through the air for short distances from insectelectrocuting traps (Pickens, 1989; Broce, 1993; Tesch and Goodman, 1995; Ananth et al., 1992).

\section{EFFECTS ON MORBIDITY OF CONTROLLING FLY POPULATIONS}

Natural populations of flies are known to harbor Campylobacter jejuni, Entamoeba histolytica, diseasecausing E. coli, Salmonella spp., Shigella spp., Staphylococcus aureus, and Vibrio cholera (Hormaeche et al., 1950; Coleman and Maier, 1956; Bolanos, 1959; Richards et al., 1961; DeCapito, 1963; Sakdisiwasdi et al., 1972; Biwald et al., 1978; Gorham, 1991; Olsen et al., 1993; I wasa et al., 1998; Sanada et al., 1998). An example of the extent to which flies may harbor foodborne pathogens is the house fly, Musca domestica. Table 2 lists examples of foodborne pathogens harbored by M. domestica. Other examples of isolations of

\section{TABLE 2}

Examples of F oodborne Pathogens I solated from Natural Populations of House Flies, Musca domestica L.

\begin{tabular}{ll}
\hline \multicolumn{1}{c}{ Pathogen } & \multicolumn{1}{c}{ Reference } \\
\hline Campylobacter jejuni & Roosef and Kapperud, \\
& 1983 \\
Entamoeba histolytica & Buxton, 1920 \\
Escherichia coli & Echeverria et al., 1983; \\
(pathogenic) & Sanada et al., 1998 \\
Salmonella typhimurium & Floyd and Cook, 1953 \\
Shigella (five species) & Levine and Levine, 1990 \\
Vibrio cholera 0139 & Sengupta et al., 1995 \\
\hline
\end{tabular}


foodborne pathogens from natural fly populations implicate blow flies (Chrysomya and Phaenicia) as harboring Salmonella, E. coli, and Shigella (Sulaiman et al., 1988; Paraluppi et al., 1996). In addition, researchers have discovered natural harboring of infective parasites (Giardia, Taenia, Ascaris, and Trichiurus) on Oriental latrine flies, Chrysomya megacephala (F.); house flies, Musca domestica L.; and flesh flies, Sarcophaga sp. (Harris and Down, 1946; Lawson and Gemmell, 1985; Sulaiman et al., 1988, 1989; J ackson and Mahady, 1989; Mariluis et al., 1989; Monzon et al., 1991).

E pidemiological studies have been conducted to determine the effect that reducing fly populations has on the morbidity of foodborne enteric disease. To date, studies have focused on shigellosis with secondary efforts to assess the impact of fly control on salmonellosis. Levine and Levine (1990) thoroughly reviewed these studies, which are summarized below. The available epidemiological studies indicate that certain flies are a significant factor in the spread of foodborne diseases and that control of fly populations is an important factor in the prevention of enteric illnesses.

Kuhn and Anderson (1944) reported an outbreak of dysentery in a military camp that coincided with sudden population explosion of flies.

Compelling field epidemiology studies were conducted by Watt and Lindsay (1948) and Lindsay et al. (1953) in south Texas and south Georgia that found statistically significant positive correlations between fly populations and the incidence of shigellosis and salmonellosis. The studies were conducted in areas of high morbidity and moderate morbidity, respectively. The studies are significant in that fly populations were quantitatively documented with Scudder fly grids and the intervention that was taken during the studies was to suppress fly populations through pesticide applications. A study conducted in Egypt (Weir et al., 1952) also indicated correlation between shigellosis and suppression of fly populations.

Cohen et al. (1991) found a statistically significant positive correlation between fly populations and shigellosis in a military camp in the Persian Gulf. Suppression of fly populations in the camp resulted in an $85 \%$ decrease in shigellosis and a $42 \%$ decrease in the incidence of diarrheal diseases. These data were confirmed by clinical tests that demonstrated correlative changes in antibodies to Shigella and enterotoxigenic E. coli (ETEC) in equivalent groups of soldiers. The study took place in 1988 and was replicated in 1989 with similar results.

Esrey (1991) reported fly suppression studies that achieved up to $40 \%$ reductions in the frequency of diarrheal disease among children. The report concluded that even though fly suppression was effective in reducing morbidity and mortality from infantile diarrhea, it was not a sustainable form of intervention from an economic standpoint. This conclusion is disputed by other authorities (Chavasse et al., 1994).

Studies conducted in hospitals provide insight on the ability of flies, especially the house fly, to transmit foodborne pathogens such as Salmonella, Shigella, and V. cholera (e.g., Chow, 1940; Fotedar et al., 1992; Sramova et al., 1992). By isolating the impact of flies from other epidemiological factors, hospital studies demonstrate that flies are, indeed, capable of spreading foodborne diseases. These studies demonstrate a capacity to transmit foodborne pathogens that qualifies flies as a potential source of cross-contamination in any environment where sanitation lapses, giving the flies access to exposed food or food-contact surfaces (Levine and Levine, 1991).

Other studies have noted correlations between the suppression of flies and reduction of enteric disease. In a study comparing levels of bacteria in flies in Peking, China, Yao et al. noted an apparent positive correlation between numbers of bacteria per fly and incidence of enteric infections. Peffly (1953) recounts an observation of reduced infant mortality that he attributes to a fly suppression program in a village in Egypt. These studies, however, lack a statistical treatment of the data. All of the above studies include observations of resurgence of enteric disease following the termination of fly suppression programs.

\section{RISK ASSESSMENT STUDIES}

Epidemiological studies normally find that factors such as water quality, sanitation, and hygiene are the primary risk factors in the spread of many enteric diseases (eg., Yao et al ., 1929; Black et al., 1978; Zeitlin et al., 1995). Relatively little has been done in the area of risk assessment involving flies. Some risk assessment studies that do consider flies simply assess the statistical risk associated with the presence of flies (eg., Zeitlin et al., 1995). Two recent case control studies, however, explore in more detail the role of flies as passive vectors of pathogens in multivehicular situations.

The relative risk associated with fly transmission of foodborne pathogens was considered in a recent casecontrol study of diarrhea in children in Malaysia. Although untreated drinking water was the primary risk factor, exclusion of flies from food was assigned an associated minor risk factor nearly equivalent to that of hand-washing on the part of the children's caregivers (Knight et al., 1992). A similar recent study of intrafamilial transmission of cholera in India found that cholera pathogens were recovered from the washings of the hands of contacts of index cases ( 2 of 54 samples) nearly as often as the pathogen was recovered from groups of flies captured in the homes of index cases ( 1 of 26 samples). The results from control households found no cholera in 21 hand-washing samples 
and 14 fly samples (Sengupta et al., 1995). Both studies involved house flies and blow flies. While the statistical significance of these results is low the studies suggest that, in efforts to prevent these diseases, failures to control flies carry an odds ratio that is comparable to the risk of failures to wash hands.

\section{TRANSMISSION OF PATHOGENS BY FLIES}

The epidemiology studies indicate that certain flies are capable of transmitting foodborne enteric diseases on a large, occasionally epidemic, scale. Gorham (1989) notes the relative lack of proven individual cases of human illness caused by a pathogen carried to a person's food by flies. Gorham and others also note that the habits of flies, especially their indiscriminate travel between filth and food, are so well known that there is no question about the wisdom of excluding diseasecarrying flies from food and food-contact surfaces (Bohart and Gressit, 1951; Chavasse et al., 1994).

Pathogen-laden flies have been shown to travel between pathogen reservoirs and exposed food (Wilton, 1961; Mayr, 1983; Daniel et al., 1989; Khin et al., 1989; Khalil et al., 1994). In a pair of studies in Mexico, Greenberg demonstrated that house flies and blow flies transported Salmonella from a slaughterhouse to a nearby market and to nearby residential areas (Greenberg, et al., 1963; Greenberg and Bornstein, 1964). An earlier study found house flies transporting Salmonella enteriditis from a sewage pool to a kitchen three miles distant (Pepper, 1944).

Greenberg (1964) conducted a study in which he fed Salmonela typhimurium to house flies and then allowed the house flies to feed on exposed food. He then fed the fly-contaminated food to 10 volunteers. Stool samples from 6 of the 10 volunteers subsequently tested positive for $\mathrm{S}$. typhimurium where none had tested positive prior to the feeding. None of the 10 volunteers showed clinical symptoms of salmonellosis because Greenberg avoided administering the massive dose of S. typhimurium to the experimental flies that would be necessary to evoke symptoms in the test volunteers. While the relative morbidity risk from flytransmitted pathogens in food is normally small, the above studies demonstrate that this risk is not negligible or trivial.

The evidence concerning the links between flies and the spread of foodborne diseases is not easily extracted and organized due to the sheer volume of the material. The encyclopedic work of Greenberg (1971) contains a bibliography of 84 pages of journal citations for articles that establish bionomic and epidemiologic associations of flies with various diseases. Greenberg's data encompass 346 fly species in 29 families. Half of the database is devoted to veterinary medicine and diseases of animals. The portion of Greenberg's data concerned with human diseases is partitioned into 19 categories, three of which (cholera, enteric infections, and helminth diseases) are also areas of concern for the FDA regulatory mission. Greenberg's enteric infections category includes the microorganisms that are most often encountered as foodborne pathogens ( $\mathrm{E}$. coli, Salmonel la, and Shigella), while cholera and helminths are only occasionally found in food products regulated by FDA. Of the three categories that concern FDA, the pathogens in the enteric infections category form the broadest basis for refining the interpretation of fly contamination of food.

Once the information relating to foodborne pathogens is examined in detail, Greenberg's review leaves no doubt that behavior and population dynamics can make some fly species more dangerous than others as potential transmitters of disease. In addition, some segments of the human population are more vulnerable to foodborne infections that are spread by flies because of their underlying host factors (eg., underlying medical conditions). To determine which species realistically represent a serious threat of transmission of foodborne diseases, it is necessary to consider both bionomics and epidemiology.

\section{INTERPRETING THE BIONOMIC DATA}

Bionomics can address whether a particular species represents a credible threat of transmitting foodborne disease by providing answers to the following questions: (1) Does the life history of the species involve visits by the adult fly to potential reservoirs of pathogens and (2) is the species synanthropic or otherwise likely to occur in habitats where it comes in contact with food and food-contact surfaces?

The data compiled by Greenberg addresses these questions of bionomics. Table 3 lists the flies that are known to visit likely reservoirs (i.e., excrement and sewage) of the foodborne pathogens included in Greenberg's enteric infections category. The list was compiled from various sources ( $\mathrm{ames,} \mathrm{1947;} \mathrm{Wilton,} \mathrm{1961;}$ Greenberg, 1971, 1973; Mayr, 1983). A fly species was included in Table 3 only after confirmation by reports in the scientific literature of association with $\mathrm{E}$. coli, an indicator organism associated with sewage and excrement. Table 3 also lists the number of literature references given by Greenberg in support of association of each fly with $\mathrm{E}$. coli.

Seventeen of the species in Table 3 are species that Greenberg's review also associates with Salmonella and Shigella. The 17 species are recognized as medically important vectors of disease (Pittaway, 1991). A search of the literature from 1970 to present found no additional species that have been associated with all three pathogens. Fly species associated with multiple types of foodborne pathogens are, by definition, disease-causing flies. The 17 species, along with the num- 
TABLE 3

Filth Flies Associated with E. coli (Reference Citations from Greenberg, 1971)

Fly Species
Family

No. reference citations
Physiphora demandata (F.)

Sepsis punctum (F.)

Piophila case (L.)

Piophila pectiniventris Duda

Copromyza atra (Meigen)

Leptocera ferruginata (Stenhammar)

Limosina punctipennis (Wiedemann)

Scathophaga stercoria (L.)

Hylemya cinerella (Fallén)

Anthomyia pluvialus (L.)

Mydaea urbana (Meigen)

Fannia canicularis (L.)

Fannia incursurata (Zetterstedt)

Fannia scalaris (F.)

Fannia leucosticta (Meigen)

Hydrotaea dentipes (F.)

Hydrotaea irritans (Fallén)

Hydrotaea occulata (Meigen)

Ophyra leucostoma (Wiedemann)

Lasiops simplex (Wiedemann)

Phaonia incana (Wiedemann)

Phaonia querceti (Bouche)

Muscina stabulans (Fallén)

Synthesiomyza nudiseta (Wulp)

Orthellia caerula Wiedemann

Musca domestica L.

Musca larvipara Porchinskii

Haemotobia irritans (L.)

Stomoxys calcitrans (L.)

Cochliomyia macellaria (F.)

Chrysomya megacephala (F.)

Chrysomya pinguis (Walker)

Chrysomya putoria (Wiedemann)

Phormia regina (Meigen)

Protophormia terraenovae (R.-D.)

Lucilia caesar (L.)

Phaenicia cuprina Wiedemann

Phaenicia sericata (Meigen)

Aldrichina grahami (Aldrich)

Calliphora vicina (R.-D.)

Calliphora vomitoria (L.)

Cynomyopsis cadaverina (R.-D.)

Sarcophaga argyrostoma (R.-D.)

Sarcophaga carneria (L.)

Sarcophaga haemorrhoidalis (Fallén)

Sarcophaga hirtipes Wiedemann

Sarcophaga melanura Meigen
Otitidae

Sepsidae

Piophilidae

Piophilidae

Sphaeroceridae

Sphaeroceridae

Sphaeroceridae

Scathophagidae

Anthomyiidae

Anthomyiidae

Muscidae

Muscidae

Muscidae

Muscidae

Muscidae

Muscidae

Muscidae

Muscidae

Muscidae

Muscidae

Muscidae

Muscidae

Muscidae

Muscidae

Muscidae

Muscidae

Muscidae

Muscidae

Muscidae

Calliphoridae

Calliphoridae

Calliphoridae

Calliphoridae

Calliphoridae

Calliphoridae

Calliphoridae

Calliphoridae

Calliphoridae

Calliphoridae

Calliphoridae

Calliphoridae

Calliphoridae

Sarcophagidae

Sarcophagidae

Sarcophagidae

Sarcophagidae

Sarcophagidae
1

1

3

1

1

1

1

1

1

1

1

$5^{a}$

1

3

1

1

1

1

3

1

1

a Also associated with Salmonella and Shigella.

ber of references from Greenberg (1971), are listed in Table 4.

There are additional criteria for categorizing a disease-causing filth fly as a possible threat to human health. In order to transmit foodborne pathogens to humans, a fly must be synanthropic (living around human settlements). A fly that lives only in remote areas away from people is not a threat to human health. The 17 flies that are listed in Table 4 as associated with the three common foodborne pathogens are all definitely categorized as synanthropic (J ames, 1947; Bohart and Gressitt, 1951; Greenberg, 1971, 1973).

Another factor to consider is whether a species exhibits "communicative" behavior. Greenberg (1971) defines communicative as "oscillating between the contaminated environment and man's surroundings." A disease-causing filth fly that is not attracted to human food as well as to potential reservoirs of pathogens is unlikely to represent much of a threat in terms of 


\section{TABLE 4}

Number of Literature References (from Greenberg, 1971) for Associations of Flies with Foodborne Pathogens

No. References for

Association with

Fly species

E. coli

Salmonella

Fannia canicularis

Fannia scalaris

Muscina stabulans

Musca domestica

Cochliomya macellaria

Stomoxys calcitrans

Chrysomya megacephala

Chrysomya putoria

Phormia regina

Protophormia terraenovae

Lucilia caesar

Phaenicia sericata

Calliphora vicina

Calliphora vomitoria

Cynomyopsis cadaverina

Sarcophaga carneria

Sarcophaga haemorrhoidalis enteric disease is difficult to evaluate because of the epidemiological complexity and multivehicular spread of foodborne diseases generally. Greenberg (1973) reviews a total of 38 journal articles reporting reductions in enteric disease correlated to fly suppression, but the authors of these articles rarely reported identifications of the fly species or supportive statistical analysis. Three flies, however, were involved in recent studies where the suppression of these specific flies is statistically correlated to significant reductions in morbidity from enteric infections. These flies are Musca domestica, Chrysomya sp., and Phaenicia sericata (Levine and Levine, 1990; Cohen, 1991).

Other key epidemiological considerations are the mobility of flies and the sizes of fly populations. Because of their mobility, disease-causing flies are capable of delivering viable pathogens from remote reservoirs to food and food-contact surfaces (Greenberg, 1964; Greenberg et al ., 1963; Greenberg and Bornstein, 1964; Wilton, 1961). This is an important HACCP consideration because delivery of viable pathogens to food or food-contact surfaces at a point subsequent to the application of a biocidal processing step may render the biocidal step ineffective. Another mobility consideration is the spread of exotic fly species that are more efficient carriers of pathogens. For example, the blow fly Chrysomya megacephala (F.) (Calliphoridae) has invaded North and South America within the past two decades (Olsen and Sidebottom, 1990; Hogue, 1993). This invader displaces native flies and represents a much greater health hazard in terms of capacity to deliver pathogens to foods (Greenberg, 1988; Olsen, et al., 1993).

The question of whether an organism as small as a fly can deliver an infective dose of a pathogen to an exposed food has not been scientifically explored. The actual number of cells that a single fly can carry and transfer to a food may not be a critical factor. The flies that are associated with foodborne pathogens often exhibit clustering and swarming behavior that ensures that large numbers of them will visit a particular site on an exposed food (Kano, 1958; Olsen et al., 1993; Godoy et al., 1996) with a cumulative effect that overpowers the carrying capacity of a single fly. Numbers of flies may be the most important factor in this respect.

Fly populations can explode with tremendous numbers in a short period of time (Norris, 1965). A recent forensic study of fly migration in Louisiana reported adult emergences of $P$. sericata and other blow flies from the ground at the rate of 2370 per $\mathrm{m}^{2}$ in the vicinity of a simulated cadaver (Tessmer and Meek, 1996). Such impressive numbers help put a perspective on the risk of allowing the above pests uncontrolled opportunities to repeatedly visit exposed food.

High densities of flies increase the load of pathogens that are delivered to a food or food-contact surface. The clustering and aggregation behaviors that are charac-

The effectiveness of suppression of flies to prevent 
teristic of some disease-causing flies (e.g., Olsen and Sidebottom, 1990; Godoy et al., 1996) concentrate the delivery of pathogens to sites where infective doses may quickly accumulate. The situation is analogous to that of contact by unwashed hands or utensils, where a single touch from an unwashed finger does not necessarily deliver an infective dose of pathogens to a food but multiple contacts, which are virtually assured, increase the odds of cross-contamination with each successive exposure of the food product to a potential source of cross-contamination (Lindsay and Scudder, 1956).

From an epidemiological standpoint the prevention of intestinal myiasis is more straightforward. Intestinal myiasis is prevented by suppression of the fly species that are the causative agents (J ames, 1947; Zumpt, 1965). Other preventive measures may include visual examination of food before consumption, excluding myiasis-causing species from contact with food, or thorough cooking of food to kill myiasis-causing maggots.

\section{REVISITING THE CONCEPT OF A "FILTH FLY"}

The taxonomic families that are included in the FDA category of "filth fly" (Wisnioski, 1994) were chosen on the basis that each family contains members that breed in excrement or have otherwise "filthy" habits or behaviors (eg., visiting garbage or feces, breeding in cadavers, etc.). As noted in the introduction, not all members of a particular family share the same habits or behaviors. Breeding in excrement, however, is one criterion for defining what constitutes a filth fly. Coliforms, especially E. coli, are considered a reliable indicator of fecal contamination. The data presented above indicate that at least 47 fly species are filth flies based on their proven association with $\mathrm{E}$. coli and known attraction to excrement or other filth. Table 3, containing these 47 species, is a core list of known filth fly species.

The use of Table 3 as a core list of filth flies is consistent with conclusions drawn by modern medical entomologists. Godard (1993) defines filth flies as members of the families Muscidae, Calliphoridae, and Sarcophagidae, a position he shares with other medical entomologists (cf. Harwood and J ames, 1979). The vast majority of the flies in Table 3 belong to these three families.

Association with filthy habitats, however, does not necessarily mean that a fly is actually capable of transmitting pathogens to humans. Very few of the "filth flies" listed in Table 3 can, within reason, be so strongly associated with the transmission of disease as to pose a serious threat to the public health. Three genera of flies have been statistically proven through fly suppression and other epidemiological studies to be capable of transmitting foodborne pathogens to humans.
These flies share certain attributes that account for their strong association with the transmission of foodborne disease. These shared attributes (from Greenberg, 1971) are: (1) wild (natural) populations associated with E. coli, Salmonella, AND Shigella, (2) synanthropy (preferring human habitats), (3) endophily (entering buildings), (4) communicative behavior, (5) attraction to both excrement and food products, and (6) recognition by medical entomology authorities as potential threats to public health from the transmission of enteric pathogens.

Flies that share in common the above attributes are a more serious public health concern than the majority of the filth flies listed in Table 3. The flies from Table 3 that meet the above criteria all belong to the genera Musca, Chrysomya, Phaenicia, Calliphora, Cochliomyia, Cynomyopsis, and Sarcophaga (includingJ antia).

As a reasonable precaution, the flies listed above should be considered a potential health hazard even though epidemiological suppression studies have yet to be conducted for all. This conclusion is based on the bionomic attributes shared with the three pathogencarrying flies for which suppression studies have established a positive correlation between flies and enteric disease.

In addition to the known carriers of foodborne pathogens, it is necessary to consider the myiasis-producing flies that are direct agents of foodborne disease. Table 5 extracts the fly species of the above genera from Table 4 that are known carriers of multiple types of pathogens and combines these species with seven additional species (Table 1) that are known agents of intestinal myiasis but not always strongly associated with the transmission of pathogens. The combined list in Table 5 represents the fly species that are convincingly documented in the scientific literature as having the six attributes (described above) for defining a fly species as a reasonably likely agent of foodborne disease in human beings.

\section{FILTH FLIES IN THE HACCP ENVIRONMENT}

The presence of disease-causing flies in a food-handling establishment constitutes a potentially hazardous HACCP situation (Gorham, 1989). The threat posed is the threat of a contributing factor that could cross-contaminate food with in-plant pathogens, contaminate food with pathogens or myiasis-causing larvae, or circumvent an otherwise effective biocidal critical control point.

Current HACCP regulations found in 21 CFR 123.11(b)(8) (Food and Drug Administration, 1997a) and related Good Manufacturing Practice (GMP) regulations in 21 CFR 110.20(a)(1), 21 CF R 110.35(c), and 21 CFR 110.37(f) require the exclusion of pests from areas where food is manufactured, packed, or held 
TABLE 5

Examples of Flies That Pose a Potential Health Hazard from Foodborne Disease

Species

Hermetia illuscens (L.)

Megaselia insulana Brues

Eristalis tenax (L.)

Piophila casei (L.)

Fannia canicularis (L.)

Fannia scalaris (F.)

Musca domestica $\mathrm{L}$.

Muscina stabulans ( $F$ allén)

Stomoxys calcitrans (L.)

Calliphora vicina (Robineau-Desvoidy)

Calliphora vomitoria (L.)

Chrysomya megacephala (F.)

Chrysomya putoria (Wiedemann)

Cynomyopsis cadaverina (R.-D.)

Cochliomyia macellaria (F.)

Phaenicia cuprina Wiedemann

Phaenicia sericata (Meigen)

Phormia regina (Meigen)

Sarcophaga (=J antia) crassi pal pis (Macquart)

Sarcophaga carneria (L.)

Sarcophaga haemorrhoidalis (Fallén)

Family

Disease potential

Stratiomyidae

Phoridae

Syrphidae

Piophilidae

Muscidae

Muscidae

Muscidae

Muscidae

Muscidae

Calliphoridae

Calliphoridae

Calliphoridae

Calliphoridae

Calliphoridae

Calliphoridae

Calliphoridae

Calliphoridae

Calliphoridae

Sarcophagidae

Sarcophagidae

Sarcophagidae
Intestinal myiasis
Intestinal myiasis
Intestinal myiasis
Intestinal myiasis
Intestinal myiasis, vector of enteric pathogens
Intestinal myiasis, vector of enteric pathogens
Vector of enteric pathogens
Intestinal myiasis
Intestinal myiasis, vector of enteric pathogens
Intestinal myiasis, vector of enteric pathogens
Vector of enteric pathogens
Vector of enteric pathogens
Vector of enteric pathogens
Vector of enteric pathogens
Vector of enteric pathogens
Intestinal myiasis
Vector of enteric pathogens
Intestinal myiasis, vector of enteric pathogens
Intestinal myiasis
Vector of enteric pathogens
Intestinal myiasis, vector of enteric pathogens
(Food and Drug Administration, 1997b). Flies are specifically named in 21 CFR 110.3(j) as an example of the kind of pest that shall be excluded from food-processing and food-storage establishments (F ood and Drug Administration, 1997b). The control of flies and other pests would not normally be accomplished through the critical control points (CCPs) of a HACCP plan, but rather through prerequisite Sanitation Standard Operating Procedures. The proper venue for controlling the transmitters or vectors of foodborne pathogens is an effective sanitation and pest-exclusion program. Such a program controls and eliminates pests from food-processing areas is a mandatory prerequisite to a HACCP plan (Food and Drug Administration, 1997b).

A balanced approach to excluding flies from foodhandling and storage areas depends on differentiating between the relatively few fly species that are reasonably likely to contribute to human morbidity and mortality from foodborne disease and the many kinds of flies whose association with the spread of foodborne disease is less compelling. Failure to exclude a diseasetransmitting or disease-causing species (e.g., a species listed in Table 5) from a food-processing facility is grounds for evaluating whether an otherwise effective microbiological CCP is likely to have been circumvented or otherwise compromised by insect pests (Gorham, 1989; Olsen et al., 1993). The HACCP sanitarian must address the epidemiological question of whether there is opportunity for the fly species to contaminate the kinds of food that can support the rapid growth of the foodborne pathogens or other undesirable microorganisms which the fly species is known to transmit. The answer to this question depends not only on the bionomics of the fly but also on the foodhandling process, the intended use of the product, and other standardized HACCP considerations for the control of microbiological food safety hazards and contributing factors such as flies.

This requires that sanitation control professionals know how to recognize the adult and larval stages of the few fly species that are a potential health threat and be able to accurately connect the fly species with a reasonably likely hazard so that, if necessary, appropriate preventive and corrective actions can be taken. The level of concern appropriate for a particular fly species depends, in part, on the degree to which the species is associated with the spread of foodborne disease. It must be emphasized that there is no known health hazard associated with the vast majority of fly species.

\section{CONCLUSIONS: REGULATORY SIGNIFICANCE OF FLIES}

Flies as well as other notorious carriers of foodborne pathogens (e.g., cockroaches, mice, rats, and birds) merit serious consideration as contributing risk factors in the HACCP environment of modern food sanitation (Minette, 1984; Gorham, 1989; Olsen, et al., 1996). Because flies harbor pathogens in natural populations, it is necessary to prevent these flies from gaining access to human food and food-contact surfaces (Levine and Levine, 1991). A sanitary environment (including exclusion of flies) and safe water are among the highest priorities for reducing morbidity from foodborne disease (Khalil et al., 1994). The summary below de- 
scribes, in general terms, the potential hazards from "disease-causing flies" that should be considered in making regulatory decisions.

Flies of any species should be excluded from foodhandling areas in accordance with current HACCP and GMP regulations regarding exclusion of pests ( $\mathrm{Food}$ and Drug Administration, 1997a, b). The currently available FDA regulatory guidance for fly filth is limited in amount and scope. These criteria are published as guidelines for "filth insects" in imported seafood (Wisnioski, 1994) and as FDA Compliance Policy Guides for fly filth in various products including milk used in the manufacture of cheese products, cherries, citrus fruit juices, olives, raisins, mushrooms, spinach, tomato products, etc. (Michels and Schroff, 1996). As previously noted, the established criteria lack the levels of precision needed by modern regulators, sanitarians, and HACCP planners to accurately evaluate the true potential health risks from fly contamination. This lack of precision can result in grouping unavoidable and harmless types of fly contamination with contamination from disease-causing flies and vice versa.

The six bionomic and behavioral attributes that define whether a fly species poses a bona fide risk to human health from foodborne disease are summarized in this review. These attributes provide a more precise set of objective, scientific criteria for interpreting fly contamination of food products in both HACCP and non-HACCP food-processing environments. The attributes can be applied to fly contamination covered under existing regulatory guidelines so the guidelines can be uniformly applied and to fly contamination found in situations where no regulatory guidance exists.

Table 3 contains verified examples of flies that are associated with pathogens and insanitary conditions. The flies in Table 3 are classified as filth flies (cf. J ames and Harwood, 1979; Godard, 1993) that are objectionable and avoidable types of filth under the provisions of sections 402(a)(3) and 402(a)(4) of the Food, Drug, and Cosmetic Act.

Table 5 contains verified examples of the flies that pose potential health hazards because they either cause intestinal myiasis and/or possess the six attributes that make a species a threat to human health as a carrier of foodborne disease. In addition to being objectionable and avoidable filth, the flies in Table 5 may represent insanitary conditions "whereby a product may have been rendered injurious to health," either as causes of myiasis or as contributing factors to the spread of foodborne pathogens.

In essence, food-contaminating flies can be characterized in different ways depending on whether biocidal processing steps, intended use of the product, and other factors neutralize or eliminate the potential health hazards involved. If the potential hazards are not effectively neutralized or eliminated, the flies in
Table 5 require heightened regulatory concern under the "injurious to health" provision of section 402(a)(4). Tables 1 through 5 serve as a basis for effective public health planning in the areas of pest control in and around areas where human food is manufactured, packed, or stored. The information in these tables also provides a list of potential hazards from flies to be considered in planning pest-control programs and corrective actions to prevent or correct potential microbial contamination or cross-contamination from flies.

\section{ACKNOWLEDGMENTS}

I thank my wife, Angelina Smaserui Olsen; the honorable Demei Otobed, Minister, Ministry of Resources and Development, Republic of Palau, and the honorable J ohn Skebong, Governor, Ngaremlengui State, Republic of Palau, who supported my work in the Palau Islands which resulted in the insights into insect behavior that are applied in this review; Sherry A. Knight for her extensive contributions as entomology coordinator and technical editor; J effrey D. Wells, Ph.D. (University of California at Berkeley); Michael L. Zimmerman (FDA, Baltimore District Office); J ohn S. Gecan, Samuel W. Page, Ph.D., Karl C. Klontz, M.D., Clark Carrington, Ph.D., Marion Clower, J r., Ph.D., J ohn E. Kvenberg, Ph.D., William Horwitz, Ph.D., and Cecilia M. Wolyniak (all of the FDA Center for Food Safety and Applied Nutrition); and J . Richard Gorham, Ph.D., for support and comment on various manuscript versions.

\section{REFERENCES}

Akinbode, O. A., Hassan, J. O., and Adejinmi, A. (1989). Public health importance of market meat exposed to refuse flies. Int. J . Zoonoses 11, 111-114.

Alcivar, Z. C., and Campos, R. F. (1946). Flies as vectors of enteric pathogens in Guayaquil Rev. Ecuatoriano Hig. Med. Trop. 3, 3-14.

Ananthe, G. P., Bronson, D. C., and Brown, J . K. (1992). Generation of airborne fly body particles by four electrocution fly traps and an electronic fly trap. Int. J . Environ. Health Res. 2, 106-113.

Banks, N. (1912). The structure of certain dipterous larvae with particular reference to those in human foods. U.S.D.A. Tech. Ser. 22, 1- 44.

Barkin, J. S., MacLeod, C., and Hamelik, P. (1983). Intestinal myiasis. Am. J . Gastroenterol. 78, 560-561.

Baumgartner, D. L. (1988). Review of myiasis (Insecta: Diptera: Calliphoridae, Sarcophagidae) of Nearctic wildlife. Wildlife Rehab. 7, 3- 46.

Bean, N. H., Griffin, P. M., Goulding, J . S., and Ivey, C. B. (1990). Foodborne disease outbreaks, 5-year summary, 1983-1987. MMWR Surv. Summ. 39(SS-01), 15-23.

Biwald, S. P., Edeson, J. F. B., Ibrahim, J., and Matossian, R. M. (1978). The role of nonbiting flies in the transmission of enteric pathogens (Salmonella species and Shigella species) in Beirut, Lebanon. Ann. Trop. Med. Parasitol. 72, 117-121.

Black, R. E., Craun, G. F., and Blake, P. A. (1978). E pidemiology of common-source outbreaks of shigellosis in the United States 19611975. Am. J . Epidemiol. 108, 47-52.

Bohart, G. E., and Gressitt, J . L. (1951). Filth-inhabiting flies of Guam. Bernice P. Bishop Mus. Bull. 204, 1-152.

Bolanos, R. (1959). Frequency of Salmonella and Shigella in domestic flies collected in the city of San J ose. Rev. Biol. Trop. 7, 207210.

Borror, D. J ., Triplehorn, C. A., and J ohnson, N. F. (1989). An Introduction to the Study of Insects. Harcourt Brace, New York. 
Broce, A. B. (1993). Electrocuting and electronic insect traps: Trapping efficiency and production of airborne particles. Int. J . Environ. Health Res. 3, 47-58.

Buchanan, W. J. (1992). Transmission of cholera by flies, 1897. Salud. Publ. Mex. 34, 362-364. [Classical article]

Busvine, J . R. (1966). Insects and Hygiene, 2nd ed. Metheun, London. Buxton, P. A. (1920). The importance of the house-fly as a carrier of E. hystolytica. Br. Med. J . 1, 142-144.

Carson, N. A., and Martinez, E. F. (1967). Fly identification by the micromorphology of the head and head appendages. J . Assoc. Off. Anal. Chem. 50, 1146-1193.

Chavasse, D. C., Blumenthal, U., and Kolsky, P. (1994). Fly control in prevention of diarrhoeal disease. Lancet 344, 1231.

Chow, C. Y. (1940). The common blue-bottle fly, Chrysomyia megacephala, as a carrier of pathogenic bacteria in Peiping, China. Chin. Med. J . 57, 145-153.

Chung, P. R., J ung, Y., Kim, K. S., Cho, S. K., J eong, S., and Ree, H. I. (1996). A human case of internal myiasis in Korea. Korean J . Parasitol. 34, 151-154.

Cohen, D., Green, M., Block, C., Slepon, R., Ambar, R., Wasserman, S. S., and Levine, M. M. (1991). Reduction of transmission of shigellosis by control of houseflies (Musca domestica). Lancet 337, 993-997.

Cole, F. R. (1969). The Flies of Western North America. Univ. of California Press, Berkeley.

Coleman, P. J ., and Maier, P. P. (1956). Investigation of diarrhea in a migrant labor camp. Publ. Health Rep. 71, 1242.

D'almeida, J . M., and de Mello, R. P. (1996). Behavior of Calyptrate Diptera in relation to the choice of oviposition substrates under laboratory conditions in Rio de J aneiro, RJ, Brazil. Mem. Inst. Oswaldo Cruz 97, 131-136.

D'almeida, J . M., and Salviano, R. J . B. (1996). Feeding preference of the larvae of Chrysomya megacephala (Fabricius) (Diptera: Calliphoridae) and Ravinia belforti (Prado e Fonseca) (Diptera: Sarcophagidae) concerning different diets. Mem. Inst. Oswaldo Cruz 97, 137-138.

Daniel, M., Sixl, W., and Kock, M. (1989). Problems of housing and health of people utilizing the garbage in Cairo from the viewpoint of medical entomology. J . Hyg. E pidemiol. Microbiol. I mmunol. 33, 568-576.

De Capito, T. (1963). I solation of Salmonella from flies. Am. J . Trop. Med. Hyg. 12, 892.

Delfinado, M. D., and Hardy, D. E. (Eds.) (1975). A Catalog of the Diptera of the Oriental Region. Univ. Hawaii Press, Honolulu.

Echeverria, P., Harrison, B. A., Tirapat, C., and McFarland, A. (1983). Flies as a source of enteric pathogens in a rural village in Thailand. Appl. Environ. Microbiol. 46, 32-36.

Esrey, S. A. (1991). Interventions for the Control of Diarrhoeal Diseases among Young Children: Fly Control. World Health Organization, Geneva.

Esser, J . R. (1990). Factors influencing oviposition, Iarval growth and mortality in Chrysomya megacephala (Diptera: Calliphoridae), a pest of salted dried fish in south-east Asia. Bull. Entomol. Res. 80, 369-376.

Esser, J. R. (1991). Biology of Chrysomya megacephala (Diptera: Calliphoridae) and reduction of losses to the salted-dried fish industry in south-east Asia. Bull. Entomol. Res. 81, 33- 41.

Evenhuis, N. L., (Ed.) (1989). Catalog of the Diptera of the Australasian and Oceanian regions. BerniceP. Bishop Mus. Spec. Publ. 86, 1-1155.

Fabritius, H. (1988). Public health impact and epidemiological risk concerning synanthropic flies. Z. Gesamte Hyg. 34, 59- 61.

Ferrar, P. (1987). A guide to the breeding habits and immature stages of Diptera Cyclorrhapha. Entomographia 8, 83-98.
Ferriera, M. F., Ieng, K. K., Claro, L., Chau, G. W., Shinonaga, S., and Goto, T. (1990). Intestinal myiasis in Macao. Chin. Med. J . 8, 214-216.

Floyd, T. M., and Cook, B. H. (1953). The housefly as a carrier of pathogenic human enteric bacteria in Cairo. J . Egypt. Publ. Health Assoc. 28, 75- 85.

Food and Drug Administration (1997a). Hazard analysis and critical control point (HACCP) plan. Title21, Code of Federal Regulations, Section 123.6, 242-243.

Food and Drug Administration (1997b). Current good manufacturing practice in manufacturing, packing, or holding human food. Title 21, Code of Federal Regulations, Part 110, 198-207.

Fotedar, R., Banerjee, U., Singh, S., Shriniwas, and Verma, A. K. (1992). The housefly (Musca domestica) as a carrier of pathogenic mocroorganisms in a hospital environment. J. Hosp. Infect. 20, 209-215.

Furlanetto, S. M. P., Campos, M. L. C., Harsi, C. M., Buralli, G. M., and Ishihata, G. K. (1984). Enteropathogenic microorganisms in African flies in the genus Chrysomyia (Diptera: Calliphoridae) in Brazil. Revta. Microbiol. 15, 170-174.

Furman, D. P., Young, R. D., and Catts, E. P. (1959). Hermetia illuscens (Linnaeus) as a factor in the natural control of Musca domestica Linnaeus. J . Econ. Entomol. 52, 917-921.

Giugliano, L. G., Bernardi, M. G. P., Vasconcelos, J . C., Costa, C. A., and Giugliano, R. (1986). Longitudinal study of diarrhoeal disease in a peri-urban community in Manaus (Amazon-Brazil). Ann. Trop. Med. Parasitol. 80, 443- 450.

Godard, J . (1993). Physician's Guide to Arthropods of Medical Importance CRC Press, Boca Raton, FL.

Godoy, W. A. C., von Zuben, C. J ., and dos Reis, S. F. (1996). Larval dispersal in Chrysomya megacephala, Chrysomya putoria and Cochliomyia macellaria (Dipt. Calliphoridae): E cological implications of aggregation behavior. J . Appl. Entomol. 120, 423- 426.

Gorham, J . R. (1979). The significance for human health of insects in food. Annu. Rev. Entomol. 24, 209-224.

Gorham, J. R., (Ed.) (1981). Principles of Food Analysis for Filth, Decomposition, and Foreign Matter, FDA Tech. Bull. No. 1, Washington, DC.

Gorham, J. R. (1989). HACCP and filth in food. J . Environ. Health 52, $84-86$.

Gorham, J. R. (1991a). Filth and extraneous matter in food. Encycl. Food Sci. Tech. 847-867.

Gorham, J. R., (Ed.) (1991b). Ecology and Management of FoodIndustry Pests, FDA Tech. Bull. No. 4, Washington, DC.

Greenberg, B. (1959). Persistence of bacteria in the developmental stages of the housefly. Am. J . Trop. Med. Hyg. 8, 405- 416 and 613- 622.

Greenberg, B. (1964). Experimental transmission of Salmonella typhimurium by houseflies to man. Am. J . Hyg. 80, 149-156.

Greenberg, B. (1971). Flies and Disease, Vol. 1, Ecology, Classification and Biotic Associations. Princeton Univ. Press, Princeton, NJ .

Greenberg, B. (1973). Flies and Disease, Vol. 2, Biology and Disease Transmission. Princeton Univ. Press, Princeton, NJ .

Greenberg, B., and Bornstein, A. A. (1964). Fly dispersion from a rural Mexican slaughterhouse. Am. J . Trop. Med. Hyg. 13, 881886.

Greenberg, B., Varela, G., Bornstein, A., and Hernandez, H. (1963). Salmonellae from flies in a Mexican slaughterhouse. Am. J . Hyg. 77, 177-183.

Greenberg, B., Kowalski, J . A., and Klowden, M. C. (1970). Factors affecting the transmission of Salmonella by flies: Natural resistance to colonization and bacterial interference. Inf. Immun. 2, 800-809. 
Haines, C. P., and Rees, D. P. (1989). A field guide to the types of insects and mites infesting cured fish. FAO Fish. Tech. Paper 303, 1-33.

Hamm, L., and Olsen, A. R. (1979). Examination of frozen peeled and deveined shrimp for fly contamination. FDA Lab. Inform. Bull. 2288, 1-2.

Hale, J . H., Davies, T. A. L., and Ng Cgeng Hin, W. K. (1960). Flies (Musca domestica) in aeroplanes as vectors of faecal-borne disease. R. Soc. Trop. Med. Hyg. Trans. 54, 261-262.

Hall, D. G. (1948). The Blowflies of North America. Thomas Say Foundation, College Park, MD.

Harris, A. H., and Down, H. A. (1946). Studies of the dissemination of cysts and ova of human intestinal parasites by flies in various localities in Guam. Am. J . Trop. Med. 26, 789- 800.

Harwood, R. F., and J ames, M. T. (1979). Entomology in Human and Animal Health, 7th ed. Macmillan, New York.

Hasegawa, S., Miwata, H., Masuda, S., Naruse, H., and Ozaki, T. (1992). An infantile case of intestinal myiasis. Acta Paediatr. J pn. 34, 87- 89.

Hogue, C. L. (1993). I nsects of the Los Angeles Basin. Natural History Museum of Los Angeles County, Los Angeles, CA.

Hormaeche, E., Peluffo, C. A., and Aleppo, C. A. (1950). Investigation on the occurrence of bacteria of the genera Salmonela and Shigella in flies. Ann. Inst. Hig. Montevideo 4, 75-79.

Howard, B. J . (1929). Fig Testing. U.S. Department of Agriculture, Washington, DC.

I wasa, M., Makino, S., and Morimoto, Y. (1998). I solation of 0157:H 7 from Musca domestica Linnaeus Obihiro. Med. Entomol. Zool. 50, 39.

J ames, M. T. (1947). The flies that cause myiasis in man. USDA Misc. Publ. 631, 1-175.

J ettmar, H. M. (1940). Some experiments on the resistance of the larvae of latrine fly, Chrysomya megacephala, against chemicals. Chin. Med. J . 57, 74-85.

J umaian, N. F., Kamhawi, S. A., Nimri, F. A., and Abdel-Hafez, S. K. (1995). A case of intestinal myiasis caused by Lucilia cuprina (Wiedemann) from J ordan. J pn. J . Parasitol. 44, 361-364.

Kano, R. (1958). Notes on flies of medical importance in J apan. Bull. Tokyo Med. Dent. Univ. 5, 465- 474.

Kano, R., and Shinonoga, S. (1965). Illustrated keys to adult filth flies of J apan. 406th Med. Lab. Ann. Prof. Rep. (Supplement). U.S. Army Medical Command, J apan.

Kenney, M., Eveland, L. K., Yermarov, V., and Kassouny, D. Y. (1976). Two cases of enteric myiasis in man. Am. J . Clin. Pathol. 66, 786-791.

Khalil, K., Lindblom, G. B., Mazhar, K., and Kaljser, B. (1994). Flies and water as reservoirs for bacterial enteropathogens in urban and rural areas in and around Lahore, Pakistan. Epidemiol. Infect. 113, 435- 444.

Khin, N. O., Sebastian, A. A., and Aye, T. (1989). Carriage of enteric bacterial pathogens by house flies in Yangon, Myanmar. J . Diarrhoeal Dis. Res. 7, 81- 84.

Kilpatrick, J . W., and Schoof, H. F. (1959). I nterrelationship of water and Hermetia illuscens breeding to Musca domestica production in human excrement. Am. J . Trop. Med. Hyg. 8, 597- 602.

Knight, S. M., Toodayan, W., Caique, W. C., Kyi, W., Barnes, A., and Desmarchelier, P. (1992). Risk factors for the transmission of diarrhoea in children: A case- control study in rural Malaysia. Int. J. Epidemiol. 21, 812-818.

Kuhn, D. M., and Anderson, T. G. (1944). Bacillary dysentery epidemic in a large military organization. Am. J. Publ. Health 34, 750-755.
Kurahashi, H., Moribayashi, A., Hayashi, A., and Agui, N. (1998). Is the house fly a mechanical vector of EHEC 0157 caused outbreaks of food poisoning in J apan in 1996? Med. Entomol. Zool. 50, 40.

Laurence, B. R. (1986). Intestinal myiasis-Washington. Trop. Dis. Bull. 83, 213.

Lawson, J. R., and Gemmell, M. A. (1985). The potential role of blowflies in the transmission of taeniid tapeworm eggs. Parasitology 91, 129-143.

Lee, H. L., Chandrawathani, P., Wong, W. Y., Tharam, S., and Lim, W. Y. (1995). A case of human enteric myiasis due to larvae of Hermetia illuscens (Family: Stratiomyiidae): First report in Malaysia. Malays. J. Pathol. 17, 109-111.

Levine, O. S., and Levine, M. M. (1991). Houseflies (Musca domestica) as mechanical vectors of shigellosis. Rev. Infect. Dis. 13, 688- 696.

Lindsay, D. R., Stewart, W. H., and Watt, J. (1953). Effect of fly control on diarrheal disease in an area of moderate morbidity. Publ. Health Rep. 68, 361-367.

Lindsay, D. R., and Scudder, H. I. (1956). Non-biting flies and disease. Annu. Rev. Entomol. 1, 323-346.

Madison, K. L., Helgerson, S., Catts, E. P., Baum, L., and Kobayashi, J. (1985). Intestinal myiasis-Washington. Morbid. Mortal. Weekly Rep. 34(10), 141-142.

Mariluis, J . C., Lagar, M. C., and Bellegarde, E. J . (1989). Dissemination of enteroparasites by Calliphoridae (Insecta, Diptera). Mem. Inst. Oswaldo Cruz. 84, 349-351.

Mayr, A. (1983). Spread of infections via refuse by domestic, community and field vermin as vehicles, with special regard to human health. Zbl. Bakt. Hyg. (B) 178, 53-60.

McAlpine, J. F. (Ed.) (1987). Manual of Nearctic Diptera, Vol. 2, Agriculture Canada Monograph No. 28, Ottawa, Canada.

Michels, D. L., and Schroff, A. (1996). FDA Compliance Policy Guides. U.S. Food and Drug Administration, Rockville, MD.

Minette, H. P. (1984). Epidemiologic aspects of salmonellosis in reptiles, amphibians, mollusks and crustaceans-A review. Int. J . Zoonoses 11, 95-104.

Monzon, R. B., Sanchez, A. R., Tadaiman, B. M., Najos, O. A., Valencia, E. G., de Rueda, R. R., and Ventura, J. M. (1991). A comparison of the role of Musca domestica (Linnaeus) and Chrysomya megacephala (Fabricius) as mechanical vectors of helminth parasites in a typical slum area of metropolitan Manila. Southeast Asian J. Trop. Med. Publ. Health 22, 222-228.

Nagakura, K., Kawauichi, K. Y., Tachibana, H., Kaneda, Y., Shinonaga, S., and Kano, R. (1991). Three cases of intestinal myiasis in J apan. J . Infect. Dis. 163, 1170-1171.

Norris, K. R. (1965). The bionomics of blowflies. Annu. Rev. Entomol . 10, 47- 68 .

North, D. E., Matteson, K. L., Helgerson, S. D., Richards J r., F., Stewart, J. M., Baum, L., and Catts, E. P. (1987). Intestinal myiasis in a baby attending a public health clinic. Nurse Pract. 12(5), 60-63.

Okaeme, A. R. (1986). Flies (Diptera) infesting landed fresh water fishes of the Kainji Lake area, Nigeria. Int. J . Zoonoses 13, 49-53.

Oldroyd, H. (1964). The Natural History of Flies. Weidenfield and Nicolson, London.

Olsen, A. R. (1988). Recognition of the wings of some major filth fly families. FDA Lab. Inform. Bull. 3237, 1-8.

Olsen, A. R. (1996). Flies (Insecta: Diptera). In Fundamentals of Microanalytical Entomology (A. R. Olsen, T. H. Sidebottom, and S. A. Knight, Eds.), pp. 71-92. CRC Press, Boca Raton, FL.

Olsen, A. R., and Sidebottom, T. H. (1990). Biological observations on Chrysomya megacephala (Fabr.) (Diptera: Calliphoridae) in Los Angeles, California, and the Palau Islands. Pan-Pac. Entomol . 66, 126-130. 
Olsen, A. R., Angold, S. C., Gross, D. F., and Sidebottom, T. H. (1992). New record of the blowfly, Chrysomya megacephala (Fabr.) from Ecuador (Diptera: Calliphoridae). Pan-Pac. Entomol . 68, 280-281.

Olsen, A. R., Sidebottom, T. H., and Bennett, S. G. (1993). The Oriental latrine fly, Chrysomya megacephala (Fabricius 1794) (Diptera: Calliphoridae), as an invading fly of public health importance. Bull. Soc. Vector Ecol. 18, 133-146.

Olsen, A. R., Sidebottom, T. H., and Knight, S. A. (1996). Fundamentals of Microanalytical Entomology. CRC Press, Boca Raton, FL.

Pape, T. (1996). Catalog of the Sarcophagidae of the world (I nsecta: Diptera). Mem. Entomol. 8, 1-560.

Paraluppi, N. D., de Vasconcelos, J . C., de Aquino, J . S., Castellon, E. G., and do, M., da Silva, S. B. (1996). Calliphoridae (Diptera) in Manaus. IV. Bacteria isolated from blowflies collected in street markets. Acta Amazon. 26, 93-96.

Peffly, R. L. (1953). Crosses and sexual isolation of Egyptian forms of Musca domestica. Evolution 7, 65-75.

Peppler, H. J. (1944). Usefulness of microorganisms in studying dispersion of flies. Bull. U.S. Army Med. Dep. 75, 121-122.

Pickens, L. G. (1989). Factors affecting the distance of scatter of house flies (Diptera: Muscidae) from electrocuting traps. J . Econ. Entomol. 82, 149-151.

Pittaway, A. R. (1991). Arthropods of Medical and Veterinary Importance: A Checklist of Preferred Names and Allied Terms. CAB International.

Radvan, R. (1960). Persistence of bacteria during development in flies. Folia Microbiol. 5, 50-56, 85-92, 149, and 156.

Richards, C. S., J ackson, W. B., DeCapito, R. M., and Maier, P. P. (1961). Studies on rates of recovery of Shigella from domestic flies and from humans in the southwestern United States. Am. J . Trop. Med. Hyg. 10, 44- 48.

Rogers, N. (1989). Germs with legs: Flies, disease, and the new public health. Bull. Hist. Med. 63, 599-617.

Rosef, O., and Kapperud, G. House flies (Musca domestica) as possible vectors of Campylobacter fetus subsp. jejuni. Appl. Environ. Microbiol. 45, 381-383.

Sabatino, F. J . (1954). Identification of insect setae as an index of contamination in dairy products. J. Assoc. Off. Agric. Chem. 37, 960-966.

Sacca, G. (1964). Comparative bionomics in the genus Musca. Annu. Rev. Entomol. 9, 341-358.

Sakdisiwasdi, O., Achananuparp, S., Limsuwan, A., Nanna, P., and Barnyen, L. (1982). Salmonella and Shigella carrier rates and environmental sanitation in a rural district, Central Thailand. Southeast Asian J . Trop. Med. Publ. Health 13, 380-384.

Sanada, H., Buma, R., Kamei, M., Maeda, T., and Kourai, H. (1998). Isolation and identification of vero cytotoxin-producing Escherichia coli 0157 from world-living Diptera. Med. Entomol. Zool. 50, 38.

Scott, H. G. (1964). Human myiasis in North America (1952-1962 inclusive). Fla. Entomol. 47, 255-261.

Scott, H. G., and Littig, K. S. (1964). Flies of Public Health Importance and Their Control. CDC, Atlanta, GA.

Sengupta, P. G., Sircar, B. K., Mandal, S. K., Mukhopadhyay, A. K., Nair, G. B., Gupta, D. N., Ghosh, S., Saha, N. C., Deb, B. C., Sikder, S. N., Manna, B., Bhattacharya, S. K., De, S. P., and Mandal, B. K. (1995). Epidemiology of Vibrio cholerae 0139 with special reference to intrafamilial transmission in Calcutta. J . Infect. 31, 45- 47.

Sharma, H., Dayal, D., and Agrawal, S. P. (1989). Nasal myiasis: Review of 10 years experience. J . Laryngol. Otol. 103, 489-491.

Shimizu, F., Hashimoto, M., Taniguchi, H., Oota, W., Kakizawa, H., Takada, R., Kano, R., Tange, Y., Kaneko, K., Shinonaga, S., and Miyamoto, K. (1965). Epidemiological studies on fly-borne epidem- ics. Report I. Significant roles of flies in relation to intestinal disorders. J pn. J . Sanit. Zool. 16, 201-211.

Shiota, T., Yoshida, Y., Hirai, S., and Torii, S. (1990). Intestinal myiasis caused by Parasarcophaga crassipal pis (Diptera: Sarcophagidae). Pediatrics 85, 213-217.

Skidmore, P. (1985). TheBiology of the Muscidae of the World. Dr. W. J unk Publ., Netherlands.

Sramova, H., Daniel, M., Absolonova, V., Dedicova, D., J edlickova, Z., Lhotova, H., Petras, P., and Subertova, V. (1992). E pidemiological role of arthropods detectable in hospital facilities. J. Hosp. Infect. 20, 281-292.

Sulaiman, S., Sohadi, A. R., Yunus, H., and I berahim, R. (1988). The role of some cyclorrhaphan flies as carriers of human helminths in Malaysia. Med. Vet. Entomol. 2, 1- 6.

Sulaiman, S., Aziz, A. H., Yunus, H., and Sohadi, A. R. (1988). I solations of enteropathogenic bacteria from some cyclorrhaphan flies in Malaysia. Malays. Appl. Biol. 17, 129-133.

Sulaiman, S., Sohadi, A. R., and J effery, J . (1989). Human helminth parsasite burdens on cyclorrhaphan flies (Diptera) trapped at an aboriginal settlement in Malaysia. Bull. Entomol. Res. 79, 625629.

Tachibana, H., Sasao, M., Tanaka, T., Nagakura, K., Kaneda, Y., Shinonaga, S., and Kano, R. (1987). A case of intestinal myiasis in J apan. Tokai J . Exp. Clin. Med. 12, 349-352.

Tesch, M. J ., and Goodman, W. G. (1995). Dissemination of microbial contaminants from house flies electrocuted by five insect light traps. Int. J . Environ. Health Res. 5, 303-309.

Tessmer, J . W., and Meek, C. L. (1996). Dispersal and distribution of Calliphoridae (Diptera) immatures from animal carcasses in southern Louisiana. J . Med. Entomol. 33, 665- 669.

Thomas, G., and J esperson, J . B. (1994). Non-biting Muscidae and control methods. Rev. Sci. Tech. 13, 1159-1173.

Umeche, N., and Mandah, L. E. (1989). Musca domestica as a carrier of intestinal helminths in Calabar, Nigeria. East Afr. Med. J . 66, 349-352.

Verhoestraete, L. J ., and Puffer, R. R. (1958). Diarrhoeal disease with special reference to the Americas. World Health Org. Bull. 19, 23-51.

Walker, D. J ., and Donegan, L. (1988). Protection of Fish from Blowfly Infestation in the Wet Season in Malawi by Dipping in Dilute Aqueous I nsecticide Preparations before Sundrying. Overseas Development Natural Resources Institute, London.

Watt, J ., and Lindsay, D. R. (1948). Diarrheal disease control studies. I. Effect of fly control in a high morbidity area. Publ. Health Rep. 63, 1319-1334.

Weir, J . M., Wasif, I. M., Hassan, F. R., Attia, S. D. M., and Kadar, M. A. (1952). An evaluation of health and sanitation in Egyptian villages. J . Egypt. Publ. Health Assoc. 27, 52-122.

West, L. S. (1951). The Housefly: Its Natural History, Medical Importance and Control. Comstock, Ithaca, NY.

Wilton, D. P. (1961). Refuse containers as a source of flies in HonoIulu and nearby communities. Proc. Hawaiian Entomol. Soc. 17, 477- 481 .

Wisnioski, L. (1994). Filth in fresh or frozen raw shrimp. FDA I mport Alert 16-21, 1-2. [revised]

Yao, H. Y., Yuan, I. C., and Hiue, D. (1929). The relation of flies, beverages and well-water to gastro-intestinal diseases in Peiping. Natl. Med. J . China 15, 410-418.

Zeitlin, M. F., Ahmed, N. U., Beiser, A. S., Zeitlin, J . A., Super, C. M., and Guldan, G. S. (1995). Developmental, behavioural, and environmental risk factors of diarrhoea among rural Bangladeshi children of less than two years. J. Diarrhoeal Dis. 13, 99-105.

Zumpt, F. (1965). Myiasis in Man and Animals in the Old World. Butterworths, London. 